\title{
Marketing Communications in the Digital Economy
}

\author{
Arsen Khalilov ${ }^{1},{ }^{*}$ Sergey Shestov ${ }^{1}$, Viktor Shinkarenko ${ }^{1}$ \\ ${ }^{1}$ Educational trade union establishment of higher professional education "Academy of Labor and Social Relations", \\ Russia \\ "Email: el8a8@mail.ru
}

\begin{abstract}
The consideration of the development potential of marketing communications in the forming digital economy is the purpose of this paper. The digital economy, stemming from the data bulk, cloud servers and digital platforms, results in transforming the marketing requirements and marketing communications.

The methods of research used the system analysis, analysis of scientific literature on marketing, marketing communications and developing the digital economy, as well as social sciences.

The authors obtained the following results: there was given the analysis of the modern digital technology development; prospects for the development and use of digital technologies in marketings and marketing communications were considered; forecasts of the possible development of marketing and marketing communications were given; there was demonstrated the influence of digital technologies on formation of the digital economy, behavior of target consumers and transformation of the whole society.
\end{abstract}

Keywords: Digital economy, Digital technologies, Marketing communications, Information, Goods.

\section{INTRODUCTION}

A modern approach in the field of communications is impossible without digitizing the social and economic space. The greater part of economic agents communicate in the market using the modern technologies, with reference to which the interaction between themselves is built.

The independent development of the economy without understanding the needs and requirements of consumers with the continuous growth of the economy under the influence of scientific and technological progress came to its limit in the first half of the $\mathrm{XX}$ century.

Successful competition required the continuous implementation of modern technologies not only in the production area, but also in all other areas of the company. Marketing became one of these new technologies appeared at the beginning of the XX century [1-3].

\section{MARKETING AND MARKETING COMMUNICATIONS AS A NEW BUSINESS PHILOSOPHY}

If traditional marketing until the $1950 \mathrm{~s}$ was synonymic with the word "sales", then modern marketing has not only a widespread practical activity, but also a well-developed theory of marketing, and "sales" became only an integral part of it (Katz, D.) [3]. Modern marketing can be compared to a kind of link between the market and the enterprise, and the market in marketing serves as the target customers consuming the goods that satisfy their needs. Without marketing, the manufacturer does not know the buyer`s needs, and the buyer does not know about goods that can satisfy his needs. A feature of modern marketing lies in the fact that enterprises produce only those goods that satisfy the needs, at which point, they become marketable. Therefore, on the one hand, marketing is focused on revealing the existing needs and, on the other hand, just as important, on developing the new needs. The abundance of existing goods on the market, disappearing old goods and permanently appearing new goods cause the problems for the consumer in the search and selection of goods [5-7]. All 
this abundance and variety of goods can become known to the target audience only through marketing communications. Modern marketing allows, by researching the target markets, to identify the needs, select the most promising of them, and then develop goods for their satisfaction, and by means of marketing communications, inform target audiences about the availability of these goods in order to organize a mass demand for them.

"Marketing communications is a process of transferring information on goods to a target audience" [5]. The target audience refers to all consumers of goods of manufacturers. Representatives of the target audience are not concentrated in any one place, but are randomly distributed among the entire population of not only a settlement, city, country, but the whole world. Therefore, the purpose of marketing communications serves as the transmission of necessary information on the item of goods for both the target audience and all possible potential buyers of this product, as well as information on the brand and information on the company to form its positive image. The sales of goods to as more as possible quantity of consumers, the market-share gain and the further development of the company, as well as the access to other markets is the strategic target of marketing communications. To address to their audience, the companies can use the mix of marketing communications which "includes advertisement, promotion of sales, public affairs and press materials for publicity formation, personal sales and direct marketing" (Kotler, P., \& Keller, K. L.) [4]. Marketing communications are a powerful tool focused on searching and informing the core audience.

The development of the digital technologies market in Russia is characterized by declining the role (table 1) of conventional marketing communications [8]. It is related to the fact that the population Internet coverage is growing and online marketing is rapidly developed, as well as Internet-trading is developed.

The vigorous growth and spread of information technologies makes it possible to cover ever-greater audiences of target users. With the advent of the Internet and digital mobile communications, marketing communications become increasingly diversified and more and more important in informing the consumers about goods and their manufacturers. The new technologies and the ever-increasing role of marketing, which is an integral part of almost any company, resulted in the search of new management methods as well. As a result, marketing management appeared as the response to the ever-increasing role of marketing which is consumer-oriented as much as possible, focused on the fullest satisfaction of consumer`s needs and demands and thus the role of marketing communications has increased.

The development of communication media and the market fragmentation resulted in a situation where the information flow increased sharply and the whole information flow is perceived by buyer as some whole entity. Acquired information from variable marketing communications forms the consumer's perception about the trade mark and image of the company. The excessive information flows, turned on the consumer, resulted in formation of the new conception of marketing communications. The model of integrated marketing communications was developed in 1993 by Shultz, Tannenbaum, Lauterborn [7], which can be considered as a logical development step for conventional marketing communications. The combined use of all marketing communications as a whole for the achievement of objects of the company is the feature of this approach. Integrated marketing communications rely upon the perception by the consumer of the whole information flow coming from the company and help the company to turn its focus toward the integrated information transmitted by different marketing communication

Table 1. The market volume of marketing communications in Russia in 2019 in relation to 2018

\begin{tabular}{|l|c|c|}
\hline \multicolumn{1}{|c|}{ Segments } & $\begin{array}{c}2019 \\
\text { (in billion rubles) }\end{array}$ & Growth \% \\
\hline Television & 175.0 & $-6 \%$ \\
\hline Radio & 16.0 & $-5 \%$ \\
\hline Press: & 15.1 & $-16 \%$ \\
Newspapers & 5.7 & $-22 \%$ \\
Magazines & 9.4 & $-13 \%$ \\
\hline Out of Home: & 43.9 & $0 \%$ \\
External advertising & 34.9 & $0 \%$ \\
Transit advertising & 5.5 & $8 \%$ \\
Indoor advertising & 2.8 & $2 \%$ \\
Advertising in cinemas & 1.1 & $-6 \%$ \\
\hline Internet & 244.0 & $20 \%$ \\
\hline Total, media advertising & 493.8 & $5 \%$ \\
\hline Total marketing services & 121.2 & $5 \%$ \\
\hline
\end{tabular}


channels and thus to obtain the whole image of the company in perception of the consumer. If outgoing information of the company is controversial, it arouses distrust of both products and image of the company. This suggests that there shall be a single policy for promoting the company in all markets in order to prevent from inconsistence of information [9-11]. Information obtained by the consumer from advertising, personal sale, promotion of sales, public communication, direct marketing and packing shall not only contradict each other but also shall be coordinated and be branched but a single message containing information on the product and the company itself referred to the target audience.

\section{NEW OPENINGS OF DIGITAL MARKETING COMMUNICATIONS}

It is obvious that the digital economy operating with data bulks accumulated digitally will affect both marketing as a whole and marketing communications [12-14]. Marketing in a new era of the digital economy acquires new technologies corresponding to transformation of conventional markets and appearance of new digital goods. Digital technologies authorize the collection of data bulks that will allow to understand better the needs of consumers, but at the same time, these data bulks turn into the item of goods which becomes a sales entity. New digital goods - data bulks that firstly relate directly to the consumer will be sold by means of marketing technologies. Marketing of data bulks will be the basis of the new digital economy. The effective implementation of data bulks will require the improvement and development of new marketing communications as well.

The feature of the digital economy is the appearance of cloud technologies, data bulks, digital platforms for collection, adaptation and distribution of information, as well as creation of digital ecosystems and ecological surroundings, which will lead practically to the target orientation of communications focused not only on the consumer but on the individual as well. Various ecosystems form ecological surroundings which will have full information about society and not only about consumers. Marketing communications focused on the target audience transform from the mass target consumer to personal marketing communications representing not only the buying activity of the individual but its activity in the Internet when using the search systems and various forms of social media. Spyware will collect full information on the activity of every individual showing an interest in one or another product group, obtaining goods both online in web-shops and in conventional stores paying by means of the bank card. All personal information selected by such a way will be processed according to specific algorithms and based on individual needs and interests, marketing communications will acquire a personal nature. In many instances, they will represent various aspects of the individual's personality and for each of them, based on data obtained, the individual plan of soft influence on the buying activity will be developed by means of marketing communications. These technologies allow, based on the analysis of data bulks, to sell futures on the possible behavior of certain groups in the future and, on the basis of this data, not only create goods expected by these groups but also form the necessary marketing communications focused on these groups. It is obvious that data bulks will allow to create mass personal communications that will adapt to certain characteristics of consumers. This is not alone communication focused on the widest audience but communication that adapts to personal characteristics of consumers (aggregative communities) in such a way that it will correspond to the perception channels of some specific aggregative community composed of its various representatives [1517]. The focus of communications on aggregative communities will allow to create the personal messages focused on the whole aggregative community and then personalize this message depending on individual parameters and adapt this message in such a way as to have the maximum effect on decision-making on purchase of goods. Thus the marketing communication focused on aggregative communities consists of several levels (Mkhitaryan S. V., Tultaev T. A) [19]: 1) common communication for all representatives of the aggregative community, 2) communication based on consumer characteristics of large consumer groups within the aggregative community, 3) personal orientation of communication based on psycho-physiological and behavioral characteristics.

The economy transition to the sixth economic structure will allow robotized factories no longer mass produce in hopes that these products will be more competitive and the buyer will prefer them compared to similar goods of competitors. This will no longer be so necessary. For each consumer, databases will be created about his anthropomorphic characteristics, tastes and preferences, about his purchasing activity and activity focused on searching some goods aimed at meeting his needs. On the basis of this data, with the help of marketing communications, various goods will be offered to him, but not those finished goods that fill the warehouse to capacity, but the goods, if ordered by the consumer, taking into account his anthropometric data, will be custom-made at an automated factory and sent either to the address of residence, or to the nearest pickup point. There will be no need to adjust goods to individual tastes and needs, since the manufactured goods will fully meet all the needs of the buyer.

Traditional search for goods when visiting stores will be significantly expanded due to special sites where you can not only see photos of goods but also try them on. The program based on the anthropometric data of the individual will create a virtual image of the individual 
and this virtual individual will be able to try on the product he likes. He will be able to make some changes in this product, if he does not like something or does not satisfy him, but these changes will not only be made mechanically, but with the help of the electronic couturier program which, in accordance with fashion and different styles, will offer various options. The consumer will receive a qualified service to change the goods this or other way so that the goods correspond to certain ideas about styles and fashion. Thus the consumer of goods will be able to get all the necessary skilled advices by communication with the electronic couturier. In case of dissatisfaction with the electronic couturier, you can get a consultation from leading couturiers for a certain fee via mobile communication or video communication over the Internet. Digital marketing communications and digital robotic technologies based on data bulks allow the production of personalized goods through mass production, but taking into account personal anthropomorphic data, from food to luxury goods. Data bulks containing almost all possible information about each consumer will form various consumer programs focused on the fullest possible satisfaction of needs of this consumer, depending on many factors, for example, social status, place of residence, occupation, education, personal interests and preferences, circle of friends and acquaintances, hobbies and lifestyle, etc.

\section{FEATURES OF BUILDING MARKETING COMMUNICATIONS IN SOCIAL NETWORKS}

Internet technologies make it possible to advertise the goods and services for their consumers more effectively. The growth of social networks all over the world leads to the possibility of obtaining personal data in one form or another on the Internet, thereby making it possible to more effectively set up advertising activities [18-20].

When advertising is generated based on information and requests that remain in search systems, marketing communication becomes more comfortable for the client. A situation arises in which the user receives the advertisement that corresponds to his requests, as well as to the data stored in social networks [21-22].

Social networks allow you to have a ready audience for promoting goods on the market; if before there was a problem of the target audience, now this issue has disappeared. The uniqueness of the client base is always of interest because:

- Segmentation of the virtual audience has been completed, that is, there is already a primary separation according to a certain audience characteristic which allows for faster spread in this area.

- The volume of information on clients, their preferences, as well as behavior is presented in the Internet statistics, information for specialists in this area becomes more complete with every passing day (Popov A. V.) [20].

- The accessibility, in other words, the number of smart phones is increasing in the world, the major part of requests will come from market participants who seek the necessary information in the digital economy.

- The interest of customers in voluntary participation in social networks, which allows to use advertising effectively rather than to impose products and information that may not be needed!

There are a lot of criteria that will lead to the growth of information. In turn, this trend results in the growth of analysis and the use of data by various clients.

\section{CONCLUSION}

At the present stage of the development of the world economy, digital technologies are beginning to acquire the dominant importance and the lag in this area will sharply reduce the competitiveness of not only individual companies, economic areas, but also entire countries. Taking into account the trends and prospects of the formation of the digital economy, the work analyzed and considered the possibilities of developing marketing communications and their role in the new market conditions. Digital economy provides virtually unlimited opportunities for the development and improvement of marketing technologies. The key feature of expanding the opportunities for marketing and marketing communications is the implementation of cloud technologies, data bulks, digital platforms for collecting, processing, storing and disseminating information, creation of various ecosystems that form the digital ecological surroundings. Conversion to the sixth economic order, aimed at creating robotic factories and enterprises, the widespread development of nano and biotechnology, combined with the continuous growth and development of information technologies, will radically change marketing communications.

\section{AUTHORS CONTRIBUTION}

As a result of the scientific research, the authors obtained the following results: the analysis of the development of modern digital technologies being the basis for creation of new technologies in marketing, is given; the prospects for the development and use of digital technologies in marketing and marketing communications are considered; the assumptions of the possible development of marketing and marketing communications under the influence of new digital technologies are given; the influence of digital technologies on formation of the digital economy, behavior of target consumers and transformation of the whole society is shown. 
Social media are more customer-facing. Communication is carried out naturally, in other words, the available customer requests are met from information in the base.

Based on the results obtained, it is recommended to pay attention to the active development of new digital technologies for fear of "catching up" position in the quick-change economy. Digital technologies open entirely new endless opportunities for the market development and the competitive growth of the company and require the creative approach.

\section{REFERENCES}

[1] C.P. Martinez, M.G. Castaneda, R.B. Marte, B. Roxas, Eects of institutions on ecological attitudes and behaviour of consumers in a developing Asian country: the case of the Philippines, International Journal of Consumer Studies 39(6) (2015) 575-585.

[2] C. Tanner, S. Kast, Promoting sustainable consumption: determinants of green purchases by Swiss consumers, Psychology and Marketing 20 (2003) 883-902.

[3] D. Katz, The Functional approach to the study of attitudes, Public Opinion Quarterly 24(2) (1960) 163-204.

[4] P. Kotler, \& K.L. Keller, Marketing management. Upper Saddle River, NJ: Pearson Prentice Hall, 2009.

[5] John Burnell, and Sandra Moriarty, Introduction to Marketing Communications, Upper Saddle Kiver, NJ: Prentice Hall, 1998.

[6] D.E. Schultz, S.I. Tannenbaum and R.F. Lauterborn, Integrated marketing communications: Pulling it together and making it work, Chicago: NTC Business Books, 1993.

[7] RACA summed up the results of the year in the advertising market [Electronic resource]. Retrieved from: https://www.sostav.ru/publication/itogi2019-akar-42360.html

[8] B.V. Artamonov, V.A. Borodai, L.V. Novak, A.S. Petrenko, V.Yu. Savitskaya, G.S. Tsvetkova, Marketing communications: problems, opportunities and development prospects [Electronic resource]: monograph, Email ed, Electron. text data (1 pdf file: 162 p.), Nizhny Novgorod: NOO "Professional Science", 2018. Retrieved from: //scipro.ru/conf/monographmarketing.pdf

[9] G. Hustvedt, M. Dickson, Consumer likelihood of purchasing organic cotton apparel: in uence of attitudes and self-identity, Journal of Fashion Marketing and Management 13 (2009) 49-65.

[10] H.S. Kim, M.L. Damhorst, Environmental concern and apparel consumption, Clothing and Textiles Research Journal 16 (1998) 126-133.

[11] G. Birtwistle, C.M. Moore, Fashion clothing where does it all end up? The International Journal of Retail \& Distribution Management 35 (2006) 210-216.

[12] N. Daneshvary, R. Daneshvary, R.K. Schwer, Solid-waste recycling behaviour and support for curbside textile recycling, Environment and Behaviour 30 (1998) 144-161.

[13] P. Sposato, R. Preka, F. Cappellaro, L. Cutaia, Sharing economy and circular economy, How technology and collaborative consumption innovations boost closing the loop strategies, Environmental Engineering and Management Journal 16 (2017) 1797-1806.

[14] A. Murray, K. Skene, K. Haynes, The circular economy: an interdisciplinary exploration of the concept and application in a global context, Journal of Business Ethics 140(3) (2017) 369-380.

[15] M. Geissdoerfer, P. Savaget, N. Bocken, E.J. Hultink, The circular economy - a new sustainability paradigm? Journal of Cleaner Production 143 (2017) 757-76.

[16] K. Fletcher, Slow fashion: an invitation for systems change, Fashion Practice 2 (2010) 259-266.

[17] S. Jung, B. Jin, A theoretical investigation of slow fashion: sustainable future of the apparel industry, International Journal of Consumer Studies 38 (2014) 510-519.

[18] H.J. Gam, H. Cao, C. Farr, M. Kang, Quest for the eco-apparel market: a study of mothers' willingness to purchase organic cotton clothing for their children, International Journal of Consumer Studies 34 (2010) 648-656.

[19] S.V. Mkhitaryan, T.A. Tultaev, I.V. Tultaeva, S.N. Andreev, Customer Churn Management in the Digital Economy, Creative Economy Vol. 12 Iss. 10 (2018) 1661-1672.

[20] A.V. Popov, Customer Experience Management in the Process of Digital Transformation, Marketing Communication 3 (2020) 200-208. Retrieved from: https://grebennikon.ru/article-dm0j.html

[21] D.A. Shevchenko, Integrated marketing communications: the model of professor D.A. Shevchenko, Marketing communications 3 (2019) 
176-181. Retrieved from:

https://grebennikon.ru/article-ombq.html

[22] R. Batra, K. Keller, Integrated Marketing communications: New findings, new lessons, and new ideas, Journal of Marketing: AMA/MSI Special Issue Vol. 80 (2016) 122-145. 